\title{
Land Conversion and Its Control Strategy
}

\author{
Yusriyadi $^{1}$, Aminah ${ }^{2}$ \\ \{prof.yusriyadi@gmail.com ${ }^{1}$, aminahlana@gmail.com² \\ ${ }^{1,2}$ Diponegoro University, Jl.Prof. H. Soedarto, S.H. Tembalang, Tembalang, Kota Semarang, \\ Jawa Tengah, 50275, Indonesia
}

\begin{abstract}
The focus of this paper is the land conversion from agricultural to nonagriculture. The significance of this focus is first, the argument from the realm of law or legislation that land conversion is restricted and even prohibited. Second, empirical domains, though restricted and prohibited, but in practice, there is always land conversion. There appears to be a gap between "das Sollen" and "das Sein," between "law in the books" and "law in action," or between "convicted" and "actual." This gap is assumed to have negative implications. The negative implications include not achieving community welfare, weak food security, and tenacity. There are two problems raised in this paper. First, why does land conversion from agricultural to non-agricultural take place? Second, what is the strategy of controlling the conversion of agricultural land to non-agricultural land? The study was conducted used a socio-legal approach and normative approach with a social theory about the law. From the theoretical analysis, it is found that there is a true conversion of land with various factors causing the farmers to have only narrow land. Second, the control strategy is through a policy of regulation and policy in the praxis level. The need for efforts to control land conversion to productive agricultural land is recommended, and there is a need for a strategy to control land conversion.
\end{abstract}

Keywords: Land Conversion, Control Strategy, Agricultural Law

\section{Introduction}

In everyday conversations, we often hear the "word" or the "term" of "land transfer function," or the complete transfer of land from agricultural to non-agricultural. Even the "word" or the "term" "land conversion" is generally a "term" in law or concrete in legislation, so it becomes a well-established and popular term in society.

The significance of the land conversion function, the complete conversion of agricultural land to non-agricultural, as the focus of the study has its argument background. The first argument is in the realm of law or legislation. In the realm of law, the transfer of land function has been regulated normatively in various laws and regulations, even determined some of its normative requirements by law. Even in the legislation, there is a provision for the disallowed land or has been determined normative in the form of certain conditions. However, in the empirical realm, or the realm of praxis, there is often a change of a land function.

The abundance of land conversion or the gap between "das Sollen" and "das Sein" is between "law in the books" and "law in action", or between the "punishable" and the "actual effect" (Article No. 35 of Government Regulation No. 1 the Year 2011 formulates that the land which has been established as sustainable food crops is protected and prohibited to be converted). Starting from the gap is assumed to cause various implications, even there is more negativity than positivity, such as not achieving the legal goals for 
justice, certainty and benefit, not achieving public welfare, especially food security and tenacity. This is where the need for forward-thinking as a solution in the form of the need to control the transfer of land functions.

The abundance of land conversion or the gap between "das Sollen" and "das Sein" is between "law in the books" and "law in action," or between the "punishable" and the "actual effect." Starting from the gap is assumed to cause various implications, even more, harmful than positive, such as not achieving the legal goals for justice, certainty and benefit, not achieving public welfare, especially food security and tenacity. This is where the need for forward-thinking as a solution in the form of the need to control the transfer of land functions.

Land-use change or commonly referred to as land conversion is a change in the function of a part or all of the land area from its original function (as planned) to another function. This change of function brings negative implications both to the environment and to the potential of the land itself as well as to the landowner. Land use transfer can also be interpreted as a change for other uses because of factors that mainly include the need to meet the increasing population demands and the increasing demand for a better quality of life. Land use is usually associated with the process of regional development; it can even be said that land conversion is a consequence of regional development. Most of the land conversion that occurred due to industrialization shows the existence of inequality in the control of land that is dominated by the capitalist party by basing the permit to establish an industry issued by the government.

Uncontrolled land use and over-exploitation, have negative implications for agricultural business. If the agricultural land is reduced, or even converted, it will experience a food crisis. From year to year, the area of productive land that switches function continues to increase thus implies the occurrence of decreased food production and threaten food security, while the food needs of the population are higher because of the rapid population growth.

It is assumed that the Local Government Policy concerning agriculture is not entirely in favor of the agricultural sector, and more to the industrial sector. Agricultural land is treated as if it should be neglected to meet the needs of settlements better and also industry. The conversion of agricultural land is a consequence of increased activity and population and industrial development. Ironically, in addition to many land transfers, Semarang regency also encountered abandoned land, namely land that has been granted rights by the state in the form of Right of Ownership, Right of Cultivation, Building Rights on Land, Right to Use, and Right of Management, or the basis of land ownership which is not cultivated, unused, or otherwise utilized in accordance with its circumstances or the nature and purpose of granting the right or basis of its control (Article 1 Point 6 of BPN No. 4/2010).

Agriculture is naturally indispensable to sustain the life and sustainability of the ecosystem of society. This applies to the past, present, and future. The rural life sector is needed by the whole life and society of Semarang regency. However, with the conversion of agricultural land to non-agricultural land, it is predicted that the future of agriculture will be threatened. Many agricultural land share converted to housing, shopping, and industry so that productive agricultural land is decreasing. It is from this background that the importance of the study under the title "Land Function Transfer from Agricultural to NonAgricultural and Its Control Strategy."

1. Why does the transfer of land function happen?

2. What are the strategies for controlling the transfer of land function? 


\section{Methodology}

The socio-legal approach is used in the study of this paper, so that the law is understood or conceptualized not merely as an esoteric normative entity, but also understood as a part of the totality of social systems that are in an interrelated position with the social variables in which they are situated, so that it is not merely a matter of studying the transfer of land from its legal aspect/legislation (which prohibits and/or regulates land conversion). Non-legal aspects or aspects outside of legislation also complement this study.

\section{Findings}

\subsection{The Factors of Land Function Transfer}

Industrial development, whether in an industrial area or not needs the existence of lands. In the policy of determining the building of the industry in specific land/field, the land policy as the part of national agrarian politics tends not to work; thereby, there is no any legal translation to it.

The legal basis of national land politics was Article 14 clause (1) of UUPA 1960 which obliges the government to plan the supply, designation, and the use of land, water, and space along with its natural resources. In the era of industrialization, this obligation should be actualized through Law regarding the use of management of water, space, and natural resources. Under this law, it is hoped to control the determined location of the industry. The determination will not only be based on the strategic planning for transportation, the existence of cheap materials, and human resources; it should also consider the fertility of the land. Ironically, the current policy only sees the considerations of material resources, the location of factory's market, transportation, human resources, and power; thus, making the fertility of the land on society's behalf is neglected.

The nonexistence of land management law (except Government Regulation Number 16 the Year 2004 regarding land stewardship) as mentioned in UUPA 1960 brings the smooth transfer of land function from farming to non-farming; therefore, the transfer becomes pervasive. From a social perspective, it is harmful and creating many social problems, since less number of farming land will imply food security.

UUPA 1960 in the category of law as the tool of social engineering [3]does want not only the structural change between people to the land but also other things like social process. The changes are referred in the manifested function of UUPA 1960, which is placing basic principles of national agrarian policy as the tool which can bring welfare, happiness, and justice to the country and the whole society, mainly farming society.

The existence of UUPA 1960 leads people to the interpretation of the law as a product of politics. In other words, to place specific policy, there should be a lawful basis as the legalization and legitimation. Thus, the law should be adapted with the desired political direction. For this sake, there should be a clear philosophical ground. UUPA 1960 uses philosophical ground from its relation to land, which rejects individualism theory by bearing social function. The debate about the relation of law between individuals or between country and land is not a new thing. Initially, there were severe studies between experts in 1948 where the government started to design agrarian law regarding the philosophical ground which is in line to Indonesian's Independence.

Besides the existence of law theories and arguments, there are two conflicting principles, individualism and collectivism. Under the conflict from the cold war between 
the East block (socialist/communist) and West block (liberal/capitalist), Indonesia has resolved to go out from these blocks. It was assumed that in the socialist/communist model, the country is deemed as an individual (or the only individual) which has absolute rights of every land. People have the right to use/exploit it; therefore, the relation between people and the country is private.

It is different from liberal/capitalist model. Even if it is best known for its freedom, but every land is distributed to the individual, including the country as an individual. Thus, the land is owned absolutely by the individual and the country. The relation between land and country is also private. Since Indonesia was not included in both blocks, the foundation was formulated. It was agreed that the used principle is monodualism. It presents the social function of rights for land; thus, the concept of individual eigendom was rejected by the explanation that land has social function. It is signalized that monodualistic view of law is deemed as the middle way or the escape and the synthesis of individualism and collectivism (i.e., adat)[4]. Development becomes the scapegoat, which makes an impression of everything will be legal under the sake of country's development. This way is usually met in the process of land acquisition to develop many industries [5].

Through Article 6 UUPA, we have placed the concept that individual rights to certain land also include society's right. Every right of land will not be justified for an individual's behalf, which harms society. The use of land should be based on the condition, character, and rights that are useful for individuals as well as society. Land should be controlled well, and its fertility should be maintained.

Indonesians own Land, water, natural resources, and space, and they become the country's wealth. It is not only owned by individuals or a group of society. For the owner, the rights of land should see this framework as the whole nation owns it. Thus, every land which is owned should have a social function. It means the right is not absolute, where its use is for the sake of the general public. The use of lands that can harm public necessity should be prohibited. In other words, the use of land should be useful for the public. Thus the ownership, designation, and the use of land rights are based on productivity, maintained on its preservation, and owned entirely by the whole society [6].

The land is not only related to the economic thing but also law, politics, social, culture, etc. In the era of industrialization, the increasing number of industries makes the need for land increases. Even the use of productive lands (rice field and lea) which are initially used for farming will be changed to non-farming needs. The initially productive lands decrease due to industrial matters. Such lands may be entirely out for the industry and other matters supporting the industry.

Industrialization brings changes to agrarian politics from populism to capitalism. Two types of transformation assigned the initial development of capitalism, (1) natural resources are changed to become capitalists' products, and (2) farmers will be changed to become labors. In the sector of agrarian, land changes from the tool of production of society's subsistence to the production of capitalist production organization. [5]Then, although UUPA 1960 is still used, its empirical position is blurred and no longer become the basis of all rules in agrarian fields. Technical terms in agrarian become supporting capitalist development strategies, like the development through different policy regarding land acquisition for public necessity and many policies of permission to land's transfer of function. Even in the philosophical ground, the use of the social function of land ownership right is changed. The change of social function of land ownership rights happens along with its form as the behavior pattern of the owner. The regulation of obliging the owner to use the land as it is and not changing the function of the land becomes not effective. 
Based on temporary observation and supported by various sources, in Semarang regency, for instance, many land conversions occurred. The sources mentioned, among others, that the farmers in Semarang regency on average only have a land of about 2,500 square meters. In fact, to be able to live properly, at least farmers need 2 (two) hectares of rice fields. The area of rice farming in Semarang regency is still around 23,000-24,000 hectares with annual production reaching 107,000 tons of rice. The rice production can be cut if the rate of land conversion in a year to reach 30-40 hectares continues uncontrolled. It is estimated that around 300 hectares of paddy fields in Semarang are affected by Semarang-Solo toll road construction project.

The lack of agricultural products due to the small ownership of the land becomes one of the reasons farmers are so easy to sell their fields to be converted into housing. Continuous land-use change, resulting in food insecurity as food demand continues to rise, while agricultural land narrows. If these conditions continue in the absence of control efforts as protection of productive agricultural land, then productive agricultural lands will continue to be converted [6]. Ideally, agriculture for Semarang regency acts not only as a food source and worker absorber but also as a buffer land and water source in the lower region of Semarang city. Even the transfer of land into uncontrolled settlements has severely affected the river flow in the city of Semarang.

As an illustration, here is the presented data of violation to Government Regulation No. 24/1961 Article 3 regarding Absentee to farming land ownership (ricefield and lea). In Semarang regency, there is land ownership of $744611 \mathrm{M}^{2}$ which was categorized as violating the prohibition of absentee[6]. The land is also neglected by the owner, although there is a prohibition of neglecting the land. It can be meant as the reflection of individualistic life. The inequality of land ownership distribution and the actualization of individual's interest (the owner) place the land as the investment. This is due to when the law is not enforced; it is stopped to become the law. Thus it can be said that the ineffectiveness of prohibition to land function transfer as the law has stopped to become law.

Starting from the ineffectiveness of law and the existence of law policy, it can be explained that the cause of land function transfer from farming to non-farming has many reasons. The reasons are the reality of (1) the increasing intensity of population making the increasing necessity of land used for personal, like housing; (2) the tendency of landowner to place land from its economic value; (3) the intensity of industrialization insists the provision of relatively vast land for industry making the process forces the change of function from farming to industry; and (4) the high number of buyers/entrepreneur in building the industry and the interest of the owner to sell their lands [8].

These causes can be prolonged, although the existence of permission to land function transfer based on spatial plans. The consideration was for public necessity/development, making the change of policy from populist to individualistic, even capitalistic, which places land based on its economic function which access can be delegated to the market mechanism. Following the analysis of Robert B. Seidman and J William Chambliss, the social and personal force can be included as the factors of land function transfer[9].

\subsection{Strategies of Land Function Transfer}

From Indonesia's independent, there was a commitment to increase the welfare of society through agrarian politics based on justice. The commitment of this is seen from Article 33 clause (3) UUD 1945 formulating firmly that the country controls water, land, 
and natural resources for the sake of people's welfare. (See Article 33 of (3) 1945 Constitution of Indonesia)

This commitment places the country as the "frontier" of people's interest in their welfare. Starting from this commitment, it determines the operational legitimation to reach this welfare. The respected law is Law Number 5 the Year 1960 regarding the Basic Principle of Agraria or called as UUPA 1960.

The vision of UUPA 1960 with its mandate reflects the principle of populism and usually called as Indonesia's socialism. UUPA 1960 formulates that the rights of land in the conception of law base the law of fields positively. As the positive law, UUPA 1960 should be das Sollen or accepted and implied as taken for granted. In UUPA 1960, the land rights concept is based on custom, meaning the rights is not only for the owner but also on its exploitation [10].

In the vision of UUPA year 1960, there is a responsibility which should be used by the landowner [8]:

1. The obligation to use the land-based on its condition, characteristics, and goal of the land ownership; thus, the landowner should not neglect the law,

2. The obligation to use or utilize the land-based on the government's plans, like not to transfer the function of the land,

3. The obligation to use the land in the balance of individual and public behalf,

4. The obligation of the landowner to see his land not as a commodity; thus, making it as the object of speculation.

These obligations are the part of UUPA 1960, but, ironically, the empirical vision of the law is not achieved. For example, empirically, there are many land function transfer from farming to non-farming, many people use land as a commodity, the use of land as the speculated object, the use of land only for economic benefit, the use of land-based on the market mechanism, the use of land as economic function, etc. Even, people's common agenda is how to make land able to be invested for a big company [11]. This liberalization will encourage the nation's policy to ease the investment to exploit agrarian sources [11]. Many land function transfer is not allowed indicating the disobedience to the principles of UUPA 1960 as positive law.

There are several factors influencing law to be used or not to be used, including the prohibition ad requirement of land function transfer. The factors are the fear of sanction, the guarantee of interest, or even the law is suitable or not suitable to individuals' principle. Many factors play essential roles in law, which by Robert B. Seidman and William J. Chambliss, these factors are deemed as social and personal power [9].

In the context of land, Gunawan Wiradi says that the objective condition to the ownership, control, and use of lands in the society is the product of interacting factors or internal dynamics, government intervention, other party's intervention, or external factors, like multinational company, international funding, the changes of politic and world economic condition, and historical inheritance [4].

The transfer of land function from farming to non-farming follows the dynamic process along with the needs of the land, making the entrance of money economy removing social bonds between individuals and making them have dominant power to be unidentified. The money economy fulfills individual needs; thus, it dominates every aspect of society.

The high transfer of land function, from Law Number 1 the year 2011 was principally limit the transfer of function from farming to non-farming with a specific requirement. Article 35 of Government Regulation Number 1 the year 2011 formulates that the land is determined as food farms which are protected and prohibited to transfer. The government 
or local government can only do the change of function for the sake of limited public necessity, includes a. Public Road, b. Reservoir, c. Dam, d. Irrigation, e. Water channel, f, Drainage and Sanitation, g. Watery, h. Port, i. Airport, j. Train station and Railways, k. Terminal, 1. Public Safety facility, m. Nature preservation; and n. Electric power plant. As in Article 30 of Government Regulation, there is a regulation controlling the appropriateness of land function transfer as the requirement of the changes of function (Article 45 of Government Regulation). The regulation can be seen as the strategy of function changes or even as the protection to the land.

The protection of the land as the process of planning and determining, developing, guiding, controlling, and monitoring the land and its surrounding should be done continuously. Substantively, the strategies of protection and control should protect the farming land and area, guarantee the existence of the land, achieve food security, and protect its owner as of the access of the farmer, farmers' empowerment, and ecological balance.

The transfer function of land is inevitable, since it has more negative impacts on the positive ones, even to the independence and security of food. There should be a strategy for farming land protection. This strategy is not only written as the regulation but also plays its role practically. In the regulation, the determination of land location being able or not able to be transferred considers the fertility of the land. There should not be any practice of land function transfer which is based on practical consideration for personal or industrial necessity, material source, location of the company, transportation access, human resources, and power plants; but more likely to be in the fertility of the land which should be used for the people.

\section{Conclusion}

The transfer of land function is increasing. It is because of the ineffectiveness of pragmatic land law making the easiness of land function transfer for practical reasons, like housing, the tendency of seeing land from its economic value, the intensity of industrialization which causes the force of land function transfer from farming to industry.

The strategy of land function transfer will be well-done by regulation or practical policy. Through the regulation, there is the determination of land location which functions can or cannot be changed while through effective policy, land transfer of function is not only based on practical terms, like private interest or industrial interest.

\section{References}

[1] P. Hillyard,"Law's Empire: Socio-Legal Empirical Research in the Twenty-First Century,"Journal of Law and Society, Vol.34(2) p. 266-79, 2007. See also V. Gessner,\&J. M. Thomas,"Socio-Legal Research and Policy Studies: A Review of the Issues,"Law \& Policy, Vol.10(2-3) p. 85-95, 1988.

[2] C. C. Thorburn,"The Plot Thickens: Land Administration and Policy in Post-New Order Indonesia,"Asia Pacific Viewpoint, Vol.45(1), p. 33-49, 2004

[3] L. Schoenberger, D. Hall \&P. Vandergeest, "What Happened when the Land Grab came to Southeast Asia?"The Journal of Peasant Studies, Vol.44(4) p. 697-725, 2017 
[4] D. Henley,\&J. S. Davidson, "In the Name of Adat: Regional Perspectives on Reform, Tradition and Democracy in Indonesia,"Modern Asian Studies, Vol.42(4), p. 815-852, 2008.

[5] P. K. Basu,"Political Economy of Land Grab,"Economic and Political Weekly, Vol.42(14), p. 1281-7, 2007.

[6] T. Firman,"Rural to Urban Land Conversion in Indonesia during Boom and Bust Periods,"Land Use Policy, Vol.17(1), p. 13-20, 2000.

[7] D. Hall,"Primitive Accumulation, Accumulation by Dispossession and the Global Land Grab,"Third World Quarterly, Vol.34(9), p. 1582-1604, 2013

[8] N. L. Peluso,S. Afiff \&N. F. Rachman,"Claiming the Grounds for Reform: Agrarian and Environmental Movements in Indonesia,"Journal of Agrarian Change, Vol.8(23), p. 377-407, 2008

[9] J. W. Chambliss \& R. B. Seiman,Law, Order, and Power, Massachusetts: Addison Wesley Publishing Company, 1971 